Ensino, Saúde e Ambiente -V5 (1), pp. 12 -31, abril. 2012

\title{
A REPRESENTAÇÃO SOCIAL DO CONCEITO DE EVOLUÇÃO DE DARWIN POR PROFESSORES DE BIOLOGIA
}

\section{THE SOCIAL REPRESENTATION OF THE EVOLUTION CONCEPT OF DARWIN BY BIOLOGY TEACHERS}

\author{
Renata Agnoletto e Marta Bellini \\ Universidade Estadual de Londrina
}

\section{Resumo}

Neste trabalho apresentamos os resultados da investigação realizada com um grupo de dezessete professores formados em Ciências Biológicas sobre as suas representações sociais - RS - do conceito de evolução de Darwin. Os procedimentos metodológicos foram elaborados mediante uma abordagem qualitativa com a aplicação de um questionário aberto. Como resultado obtivemos a representação social de evolução do grupo de professores entrevistados ancora-se na noção de progresso. Evoluir é progredir. Essa noção é fundamentada pela ideia de um gene que dá direção à evolução. Não há o papel do acaso. O conceito de evolução apresentado pelos professores distancia-se da teoria de Darwin; é pensado como progresso genético das espécies.

Palavras-chave: Darwin, ensino de evolução, representações sociais.

\begin{abstract}
The present work results from a investigation on the social representations of Darwin's concept of evolution formulated by seventeen teachers with a degree in Biology are provided. Methodological procedures were provided through a qualitative approach by means of a questionnaire. Results show that the social representation of Evolution conceived by the interviewed teachers is based on the idea of progress, or rather, evolution is progress. Current notion is foregrounded on the idea of a gene that triggers evolution. Genes are the most important issues in Evolution and chance does not exist. The teachers' concept of Evolution, thought to be the species' genetic progress, is far from Darwin's theory.
\end{abstract}

Keywords: Darwin; Teaching Evolution; Social Representations 
Ensino, Saúde e Ambiente -V5 (1), pp. 12 -31, abril. 2012

\section{Introdução: o conceito de evolução entre Darwin e professores de ciências biológicas}

Nada em biologia faz sentido senão à luz da evolução, afirmou Dobzhansky (1900-1975). Ainda assim, a ideia de evolução na formação de professores não é certamente pensada no sentido apresentado pelos evolucionistas. Esse conceito, mesmo advindo de uma das teorias mais importantes para a Biologia com o sentido de adaptação, tem sua tradução vinculada à ideia de progresso. O que aprendemos como base da teoria de Darwin em nossa formação como professores de ensino fundamental e médio em Biologia? Evolução é adaptação das espécies ou é progresso?

Com essa pergunta realizamos uma investigação entre 2010 e 2011 tomando a teoria das representações sociais de Moscovici para compreender qual o sentido do conceito de evolução para um grupo de dezessete professores formados em Ciências Biológicas. As questões que nortearam a pesquisa foram: A representação do conceito de evolução dos professores entrevistados está ancorada no conceito de Darwin? Os professores pensam a biologia sob uma ótica evolucionista?

Os documentos oficiais para educação (BRASIL, 2006, PARANÁ, 2008) apontam a centralidade do tema evolução nos currículos de Ciências no ensino fundamental e médio. A evolução é o conceito que deveria unir todos os conteúdos da Biologia para estudar os organismos dada a sua perspectiva dinâmica dos seres vivos. Desde a publicação da obra 'A origem das espécies' por Charles Darwin, em 1859, o estudo de Biologia tem considerado as histórias evolutivas dos seres, suas genealogias e especializações que permitem a sobrevivência. A polêmica causada pela ruptura com o modelo fixista de conceber as espécies foi acompanhada pela negação da história conhecida, sobre entes superiores e barcas gigantes que abrigavam todos os seres vivos do planeta (MEYER; EL-HANI, 2005; FUTUYMA, 2002).

No século XVIII diferentes culturas já debatiam sobre a transformação das espécies. No século XIX, Charles Darwin revolucionou esse debate situando as espécies em um projeto de adaptação que explicava a mudança dos organismos ao longo do tempo; fazia afirmações sobre a origem dessas espécies e cunhava um modelo de teoria que mostrava a proximidade dos grupos de seres vivos (SACARRÃO, 1989; CAPONI, 2005).

O teor revolucionário da teoria darwiniana está na sua hipótese de adaptação. A adaptação trouxe vantagens para as espécies e permitiram sua sobrevivência. Para 
Caponi (2006) Darwin trouxe uma nova forma de compreensão dos seres vivos e foi o primeiro naturalista no sentido moderno da palavra. Isto porque ele não se preocupava com a descrição dos seres vivos, com o catálogo das espécies e sua inserção em uma organização fisiológica como fizeram os naturalistas anteriores. Darwin foi um extraordinário observador das espécies, de sua morfologia e de suas relações com outras espécies em determinados ambientes, inclusive sobre o papel da seleção sexual. Fundamentou-se na capacidade de adaptação dos seres a esses ambientes, levando em conta o papel do acaso e do tempo. Evolução é na teoria de Darwin, descendência com modificação pelo processo de seleção natural. Darwin formulou uma teoria em que as pressões ambientais operam mudanças nas condutas dos organismos, que favorecem a fixação de características morfológicas e fisiológicas vantajosas para sobrevivência das espécies. Em uma significação ampla, evolução é sinônimo de mudança e por isso, o termo é aplicável em várias áreas. Isto, no entanto pode causar confusão de significados, quando o conceito derivado da teoria darwinista é aplicado em outros campos de conhecimento.

Antes de Darwin as espécies eram aceitas como partes organizadas em uma cadeia de seres, minuciosamente descritos por Lineu e aceitos pelos naturalistas, mas inseridos em contexto estável. Toda a lógica da Ciência Natural repousava no fixismo, e esta mudança de olhar sobre as espécies gerou tanta resistência quanto às propostas de Copérnico, Kepler ou Galileu na Física, ultrapassando os limites da ciência; se não havia mais um grande planejamento para as espécies, começava um rompimento com a ideia de design e se iniciava o olhar para o acaso (DEWEY, 1997).

Apesar da distinção da teoria de Darwin, historicamente, o clima social progressista da Inglaterra no século XIX, marcou sua teoria orientada pela ideia da "sobrevivência dos mais aptos" ou a ideia de progresso. Hegemonicamente a teoria de Darwin foi compreendida como a teoria da Cadeia do Ser, em que um ser de menor complexidade era substituído por um de maior complexidade ou mais evoluído. Essa visão dos seres vivos em cadeia de progresso culminou como mostra Gould (1997) na evolução como metáfora da escada. A interpretação de que a evolução é um mecanismo de melhoria para os seres, advém dessa época, e o termo evoluir é usado comumente para referir ao aumento de complexidade com o passar do tempo, ou de aptidão para um determinado ambiente. O sentido utilizado por Darwin foi obscurecido, restando da teoria original proposta em 1859 apenas o título "seleção natural". 


\section{A pesquisa}

\section{A Retórica e a teoria das Representações Sociais como referenciais teóricos para compreender o conceito de evolução entre professores de biologia}

O ensino é principalmente uma dimensão retórica porque a maior parte de nosso tempo como professores é dedicada à fala e à construção de sentidos. Nesse percurso, nossa linguagem recorre frequentemente às analogias e metáforas para tornar mais palatável a linguagem científica. No entanto, as figuras de linguagem ou de retórica podem criar outros sentidos, bem distantes daqueles da linguagem científica uma vez que a busca da uma linguagem mais fácil aos alunos pode ser a constituição de sentidos diferentes daqueles da linguagem dos cientistas. Desse modo, os estudos sobre argumentação e das figuras de retórica compreendem a necessidade de pensar uma teoria da comunicação para entender a construção de sentidos na situação de sala de aula.

Para Perelman e Tyteca (2000), o discurso do professor tem autoridade em razão da sua posição social como porta-voz de valores comuns que não estão necessariamente estruturados, mas que a condição de educador o qualifica para fazê-lo, de maneira que obtenha adesão futura pelo auditório. Mazzotti (2008) mostra que as representações são construídas mediante valores internos dos grupos, e explica que definir o que é "preferível”, ou, em nosso caso, o discurso eleito pelos professores, é um caminho para se alcançar as representações que circulam a respeito de um assunto ou objeto.

A teoria das Representações Sociais (RS) pode ser compreendida como uma das teorias necessárias à educação isso porque as RS provêm do cotidiano pelas comunicações e contribuem para orientação das condutas sociais (JODELET, 2001). As RS são "[...] estruturas cognitivas específicas da sociedade contemporânea, que se constroem no âmago das interações e das práticas sociais" (MADEIRA, 2005, p. 205).

Ao estudarmos as RS de um grupo estamos investigando como ele compreende e se relaciona com o mundo; caracterizar uma representação social indica não apenas que o indivíduo entende um tema de maneira peculiar, mas, sobretudo que ele acredita, fala e compartilha aquele entendimento que possui. As representações sociais constituem o conhecimento compartilhado pelos grupos sociais no cotidiano, independentes das formações acadêmicas. Quando se trata de algum tema da ciência essas representações 
podem produzir uma identidade comum ao grupo provinda de uma quebra de paradigma (JODELET, 2001).

Para entender as representações sociais, deve-se levar em conta que elas muitas vezes condicionam toda a sociedade e nos são prescritivas. Este condicionamento não ocorre somente porque as representações são partilhadas entre os grupos, mas porque ao serem partilhadas e reforçadas pelas tradições se tornam uma realidade naquele grupo. As RS,

[...] convencionalizam os objetos, pessoas ou acontecimentos que encontram. Elas lhe dão forma definitiva, as localizam em uma determinada categoria e gradualmente as colocam como um modelo de determinado tipo, distinto e partilhado por um grupo de pessoas [...] Assim passamos a afirmar que a Terra é redonda, associamos o comunismo cor vermelha [...] (MOSCOVICI, 2009, p. 34).

Ou nas palavras de Alves-Mazzotti (2005), as representações sociais são ao mesmo tempo consideradas individuais e coletivas. E mesmo o indivíduo desempenhando um papel ativo em sua construção como sujeito, ele precisa, para isso, basear-se em modelos de pensamento "modelos de pensamento, e elementos simbólicos que circulam, através da conversação, no campo social em que ele está inserido" (ALVES-MAZZOTTI, 2005, p. 215-216). Esses modelos e esses elementos orientam suas condutas e ações em seu mundo e orientam sua partilha de conhecimento, constituindo o "sentimento de pertença com o grupo que partilha as representações" (ALVES-MAZZOTTI, 2005, p. 216).

\section{As entrevistas}

Para a elaboração e aplicação das entrevistas trabalhamos sob a orientação da abordagem metodológica qualitativa na qual "[...] não admitem regras precisas, aplicáveis a uma ampla gama de casos" principalmente por tratar de realidades múltiplas e flexíveis, que revelam novas realidades em cada caso analisado (ALVESMAZZOTTI, 1998, p. 147). Desse modo, privilegiamos entrevistas dialógicas para os depoimentos de um grupo de 17 professores de Ciências Biológicas.

As entrevistas do tipo participativa ou dialógica caracterizam-se pelo papel ativo

tanto do pesquisador quanto do entrevistado (ROJAS SORIANO, 2004). Essas entrevistas foram feitas com 17 professores licenciados em Ciências Biológicas. Para 
seleção dos participantes visitamos a escolas públicas de ensino fundamental e médio do município de Maringá (PR) e contatamos por e-mail professores licenciados em Ciências Biológicas do município de Cascavel (PR), local onde uma das pesquisadoras concluiu sua formação em licenciatura em Ciências Biológicas.

As entrevistas foram registradas com um gravador Samsung. Após transcrevemos os depoimentos e constituímos o corpus da investigação para o exame retórico tomando os estudos de Reboul (2004), Perelman e Tyteca (2000) e Mazzotti (2008).

\section{O roteiro da entrevista}

O roteiro para a entrevista foi constituído por sete questões formuladas com base na história da Ciência e em histórias de evolução de animais inspirado nos livros de Stephen Jay Gould.

1) Darwin, no século XIX, elaborou a teoria de evolução. Essa teoria teve muita repercussão na Inglaterra e outros países. Quais foram, em sua opinião, as repercussões da teoria da evolução de Darwin? (Objetivo: Verificar contexto histórico da quebra de paradigma).

2) A teoria da evolução de Darwin nos apresenta dois pontos centrais: A ideia de seleção natural e de adaptação. Como você apresentaria esse modelo da teoria de Darwin aos alunos se fosse proposto que você desse uma aula sobre o assunto? (Objetivo: Verificar o conhecimento que tem do modelo).

3) A teoria de Darwin como modelo explicativo da evolução das espécies pode ser aplicada nos dias de hoje? (Objetivo: Verificar se tem conhecimento sobre neodarwinismo).

4) Por que é importante estudar evolução, ou ensinar evolução na escola? (Objetivo: Verificar a compreensão da centralidade do conceito de evolução na disciplina de biologia) ${ }^{1}$.

5) Um professor estava dando uma aula de Biologia no ensino médio, na qual explicou a teoria de Seleção Natural de Darwin e falava sobre evolução quando um aluno lhe perguntou: "Professor, mas então o que é mais evoluído, uma bactéria ou um

\footnotetext{
${ }^{1}$ As questões 4, 5 e 6 foram inspiradas em questões elaboradas por Goedert (2004) em seu trabalho de dissertação de mestrado.
} 
elefante?" O que você responderia se fosse este professor? (Objetivo: Examinar a presença da ideia de progresso) $)^{3}$.

6) Alguns micro-organismos quando expostos a substâncias químicas (como os medicamentos), apresentam resistência, você acha que este é um exemplo de evolução? (Objetivo: Averiguar se consegue discernir entre o conceito de evolução e adaptação) ${ }^{3}$

7) Acompanhe os exemplos:

Exemplo 1: Uma população de tartarugas verdes, Chelonia mydas, viaja 2.000 milhas desde a costa do Brasil até a isolada ilha de Ascensão, localizada no Atlântico central para fazer seu ninho e se reproduzir. Os recém-nascidos flutuam até a costa do Brasil pela corrente equatorial e ali permanecem até sua própria época de reprodução, mas o grande enigma é como estes filhotes acham o caminho de volta para Ascensão (GOULD, 1989, p. 20).

Exemplo 2: O feto da baleia desenvolve dentes no ventre de sua mãe, mas posteriormente os reabsorve e passa toda sua vida filtrando Krill (seu alimento) através da barbatana. Possivelmente seus ancestrais tiveram dentes funcionais, e esses dentes constituam hoje um remanescente, num estágio em que já não tem significado (GOULD, 1989, p. 18).

Qual sua ideia de evolução mediante os exemplos citados? (Objetivo: Proporcionar exemplos práticos para que o professor possa repensar as ideias de evolução e adaptação, caso não tenha conseguido raciocinar a partir das questões anteriores).

Após transcrição das entrevistas cada questão teve análise específica, primeiramente criamos categorias de discursos e a partir desta categorização partimos para identificação das figuras na análise retórica.

\section{As falas dos professores entrevistados}

Em relação à primeira questão obtivemos as categorias: "O mito do precursor ou Darwin como Lamarck aprimorado"; "Evolução como resposta à religião"; "Quebra de paradigma científico"; "Ciência sem evidência"; "Evolução é a Seleção Natural".

As diferenças entre os números de professores que compõem as categorias e o número total de entrevistados devem-se as abstenções em algumas perguntas.

A primeira categoria foi denominada o mito do precursor ou Darwin como Lamarck aprimorado. Os conceitos de Darwin foram atribuídos aos aperfeiçoamentos da teoria de Lamarck por cinco professores. 
[...] é que foi entrando substituindo a de Lamarck né? No uso pelo desuso, então pra ele a seleção natural... A seleção natural caiu fora a teoria de Lamarck... [...] Daí ele uso os exemplos, se não me engano foi das girafas, [...] as que tinham pescoço maior sobreviviam pela seleção não pelo uso e desuso. $(\mathbf{P 1})^{2}$.

Bom, ele quebrou aquela teoria de Lamarck? Que então eram somente os mais fortes que... [...] que sobreviviam (P7)

A segunda categoria formulada diante de respostas de cinco professores foi evolução como resposta à religião.

[...] ia contra, o que se sabia... Principalmente quando se vai contra os princípios da igreja, que tinha uma força muito grande, isso cria polêmica. Darwin foi contra os princípios da igreja? Falar a evolução é! Por quê? Porque de acordo com a evolução nós, de acordo com a teoria da igreja, nós nascemos... Foi deus que nos criou (P9).

Um professor afirmou que a repercussão da teoria se deveu à falta de evidências, permanecendo como uma "teoria" que não tem comprovações. Nomeamos como ciência sem evidência.

É pelo fato de ser teoria, não tem um estudo científico que possa comprovar, então a partir daí já é uma polêmica [...] por ser teoria e não ter como provar... (P14).

Dois professores evocaram o conceito de evolução pelo de seleção natural, reduzindo-o a uma dimensão do processo evolutivo.

[...] a seleção natural é que com o passar do tempo o melhor se adapta? O melhor evolui! (P2).

Essa redução é feita pelo recurso da metonímia, ou seja, evolução é representada pela seleção natural. A metonímia, [...] tem principalmente uma função referencial, isto é, permite-nos usar uma entidade para representar outra" (LAKOFF; JOHNSON, 2002, p. 92). Também verificamos o uso da hipálage SELEÇÃO NATURAL, figura que tende a substituir todos os conceitos inerentes à evolução em apenas um, ou seja, "um deslocamento de atribuição" (REBOUL, 2004 p. 124).

\footnotetext{
2 As falas dos professores foram corrigidas quanto ao aspecto gramatical. As expressões centrais são ressaltadas em itálico e as supressões de texto são identificadas com reticências entre colchetes. As intervenções da pesquisadora no momento da entrevista estão apresentadas em negrito.
} 
Em relação à segunda questão formulamos as categorias: "Evolução é sinônimo de adaptação"; "Personificação da Evolução"; "Discurso do Livro Didático"; "Discurso da Genética"; "Diversidade populacional é requerida para Evolução".

Evolução é sinônimo de adaptação, é a primeira categoria em relação aos depoimentos da segunda pergunta. Nesta questão houve a valorização do processo de 'adaptação' como central no modelo de evolução. A ideia de temporalidade ficou esquecida, com exceção de um único professor que esboçou algumas considerações temporais. Também não houve muitas referências à seleção das espécies; o papel do acaso foi citado por duas professoras. O modelo darwiniano é entendido com base na capacidade do organismo mudar para acompanhar o meio ou sobreviver às mudanças deste.

A ideia do tempo e o papel do acaso são esboçados timidamente:

[...] porque isso se adaptou dessa forma o que isso traria de beneficio praquela espécie em questão. Então por exemplo, glândulas mamárias ou glândulas sudoríparas [...] E que isso foi a partir do tempo fazendo a seleção das espécies (P2).

[...] seleção natural eu falaria o seguinte: que o meio primeiro, influencia em algumas características, mas se ao acaso essas características acontecerem e o indivíduo que apresentar essa característica ele vai ser selecionado como o mais apto e ele permanece no ambiente (P3).

Dois professores trataram a evolução como uma entidade que age na natureza realizando todos os processos evolutivos. A evolução é materializada ora na 'seleção natural', ora na 'adaptação'. Ocorre personificação nessas falas, uma metáfora que permite "dar sentido a fenômenos do mundo em termos humanos" (LAKOFF; JOHNSON, 2002 p. 89). Desta forma destacamos a personificação ADAPTAÇÃO que é o 'agente' responsável pela seleção.

Se for por Seleção natural, a seleção vai selecionar o mais apto e vai elimina o menos apto (P5).

Também constatamos, em três sujeitos falas que chamamos de discurso do livro didático. Quando solicitados a dar exemplos, os entrevistados associaram o conteúdo de evolução aos exemplos dos livros didáticos. 
$\mathrm{Na}$ girafa as que tivessem pescoço maior iam conseguir se alimentar iam sobreviver... E as que não conseguissem alcançar as árvores altas, os alimentos, elas morreriam $(\mathbf{P 1})^{\mathbf{3}}$.

Lembra do exemplo das borboletas? Eu acho que é um bom exemplo (P3) ${ }^{4}$.

Sete professores explicaram o modelo da teoria evolutiva de Darwin pelo conceito de adaptação baseado em explicações genéticas.

[...] o tigre perdeu o dente, e foi uma adaptação que ele, que ele sofreu com o meio ambiente, por que a partir do momento que ele não precisava mais utiliza aquele dente, ele perdeu e isso só... Só começou a ser uma nova... Uma espécie diferenciada sem o dente a partir do momento que isso foi expresso dentro do DNA [...] (P9).

A metáfora da personificação atribui ao ambiente a intenção de gerar a adaptação dos seres vivos.

Tiveram algumas espécies que não conseguiram sobreviver [...] não conseguiram se adaptar [...] Até o homem mesmo? Alguns que apareceram que hoje não existem mais, que eles não conseguiram desenvolver maneiras, formas de sobreviver (P14).

Apenas dois professores atribuíram a outros fatores o papel devido na evolução biológica, sobretudo a necessidade de diversidade intraespecífica:

[...] a gente vê isso nas características... Alguns genes são selecionados e assim vai acorrendo gradativamente a evolução? Que é mudança! Nem melhora, nem piora de uma espécie. (P6).

Quanto à terceira questão elaboramos as categorias: "Discurso da genética"; "Discurso paleontológico"; "Darwinismo social".

Seis sujeitos afirmaram a validade da teoria se acrescida de conhecimentos da genética. A genética aparece, neste caso, como a 'salvadora' da teoria de Darwin; tudo aquilo que não se conseguia justificar nas questões anteriores, agora é atribuído à genética, ainda que não tenham falado sobre os processos genéticos propriamente ditos.

\footnotetext{
${ }^{3,4}$ Referências aos conhecidos exemplos dos livros didáticos de Biologia, que geralmente trazem na seção de Evolução os experimentos realizados pelo biólogo Bernard Kettlewell, na década de 1950 quanto ao melanismo industrial. Apresentam fotos com o registro que mostram exemplares claros e escuros de mariposas do gênero Biston repousando sobre troncos de árvores e ainda as famosas imagens de girafas com pescoços curtos e longos para exemplificar a teoria Lamarckista (ROQUE, 2003).
} 
Este é mais um caso de hipálage. Nesses discursos a genética se tornou o agente responsável pela mudança, agora ela explica a adaptação. Se perguntarmos como as mudanças ocorrem, a resposta definitiva é: 'Pela genética, mutações genéticas'. O meio ambiente que já havia sido ignorado nas outras respostas agora desaparece totalmente do contexto de evolução.

[...] acrescentando agora outras teorias né, mutação [...] a especiação [...] isolamento geográfico, isolamento reprodutivo, então junto com outras teorias eu acredito que pode ser aplicada ainda. Só que a única coisa que ele não explicava era a variação né, por que na época ainda não tinha, nem na época dele e nem de Mendel né, não se sabia sobre genética né, DNA, genes... (P6).

Quatro professores expressaram apenas uma resposta afirmativa à terceira questão; um deles apresentou o que consideramos uma visão de darwinismo social, para ele os seres humanos têm o discernimento e podem escolher se adaptar ao meio social, fazendo um paralelo com a seleção natural de Darwin para a vida psicológica.

[...] eu acho que, durante a sua graduação você tem $o$ consentimento que você pode se adaptar melhor ao meio que você vai ser o profissional, aquele meio que você escolheu, então na verdade você tem uma seleção natural pelo quanto você se adaptou a esse meio anteriormente. [...] eu particularmente aplico isso no mercado em geral, seja profissional, ou qualquer outra coisa a gente ainda vê isso ai (P12).

Dois professores utilizaram como recurso de complementação a teoria evolutiva de Darwin os estudos paleontológicos:

[...] fica difícil você ver essa evolução, então comparar, isso daí é uma coisa muito lenta [...], isso a gente consegue através dos fósseis, essas coisas (P13).

Quanto à quarta questão obtivemos as categorias: "Visão biológica"; "Antropocentrismo"; "Darwinismo Social".

Sete professores atribuíram a importância dos estudos de evolução pela necessidade de considerações evolutivas no estudo da diversidade biológica do planeta. Entretanto dois destes professores citaram (P9 e P10) também a necessidade de conhecer os antepassados humanos, sobretudo para prever evoluções futuras de nossa espécie. Este discurso da importância da evolução nos estudos biológicos pode denotar, neste grupo, um conhecimento dos documentos oficiais para o currículo escolar, verificamos que o discurso confirma o que encontramos nestes documentos. 
Eu trabalho: Monera, Plantae, mas eu deixo bastante claro: Olha o que mudo, olha a importância dessa mudança, graças a essa mudança, olha quanto essa espécie, esse reino cresceu, [...] a gente tá em constante evolução, em constante seleção natural e não tem como para de estuda isso! (P8).

Apenas uma professora reconheceu a evolução como conceito central na biologia:

Biologia não existe sem evolução! [...] Evolução não é uma disciplina separada! Não é uma coisa sozinha! Evolução está junto com qualquer outra disciplina da biologia. Biologia celular, fisiologia, ecologia... zoo! [...] então evolução é a base de qualquer outra disciplina! (P3).

Seis indivíduos apresentaram como razão principal para o estudo de evolução a tomada de conhecimento da história da vida, sobretudo da vida humana.

[...] assim de uma certa forma, nós temos que saber, da onde nós viemos na realidade, como que aconteceu, e... E por essas razões é... [...] O homem sem uma história eu não acredito que ele seja o homem (P14).

A importância de conhecer o passado da vida na Terra é a de prever situações futuras e prevenir possíveis catástrofes. O ambiente é lembrado, mas somente em relação aos efeitos das mudanças climáticas na vida humana.

Os alunos têm que entender que [...] as coisas são hoje não foram sempre como é, e tudo pode ser mudado, [...] então o que nós somos hoje, não é o que pode ser daqui alguns anos, então o ambiente pode influenciar [...] A seleção, até mesmo da espécie humana $[. .$.$] tem visto tanto desastre natural [...] essas coisas se$ aceleram (P7).

São apontadas a prevenção e a cura de doenças humanas que poderiam ser possíveis por estudos da biologia evolutiva de micro-organismos.

Por que ela está no nosso dia a dia não é? E ela hoje é utilizada na medicina, é utilizada na ecologia, então [...] não tem como você deixar de se ensinar evolução nas escolas... (P11).

Quanto à quinta questão temos as categorias: "Metáfora da Sustentação" e "Metáfora Escada".

Ao indagarmos "o que é mais evoluído uma bactéria ou um elefante?", dez professores responderam que esta comparação não pode ser feita, porque existe uma dependência do ambiente nesta avaliação. $\mathrm{O}$ ambiente aparece em nove falas como sustentação dos seres. Aqui identificamos a metáfora sustentação, o meio "socorre" e 
"ampara" os organismos e, dessa maneira, dependendo do ambiente, ele é evoluído ou não.

Para meio em que a bactéria vive, a bactéria é mais evoluída, para o meio onde o elefante está, vive, ele é mais evoluído... Isso contradiz um pouco, não é? Por que anteriormente eu falei 'ai pra gente mostra pro aluno, qual que é o indivíduo perfeito não é, a espécie perfeita, que seria nós’ (P2).

Cinco professores demonstraram claramente a metáfora ESCADA em seus discursos. Para dois deles (P4 e P9) a evolução é relacionada à maior complexidade dos seres; representa um modelo evolutivo de 'escada' em que os degraus se elevam em direção à complexidade celular. Esta visão também mostra como o modelo celular é forte nos estudos biológicos; as interações ecológicas são esquecidas e tudo se justifica em nível celular. Algumas vezes a ancestralidade os confunde, e alguns (P3, P5, P12) afirmam que os seres anteriores são mais evoluídos, o que percebemos é novamente a ideia da escada, mas desta vez os ‘degraus inferiores' são considerados mais evoluídos.

[...] o mais evoluído seria o elefante, que ele é um mamífero! [...] ele é um organismo muito mais complexo do que uma bactéria (P4).

Eu ia pegar pelas idades, por exemplo, a bactéria se ela existe até hoje em várias espécies diferentes, uma diversidade enorme então ela evoluiu. O elefante ele é bem mais recente que uma bactéria, então acredito que pela idade, seja a bactéria (P12).

Quanto à sexta questão foram elaboradas as categorias: “Alteração na população indica evolução"; "Alteração na população indica adaptação"; "Recurso à genética".

Quando proposto um exemplo de ação de substâncias químicas em microorganismos, seis professores afirmaram que tratava-se de exemplo de evolução e mesmo depois de refletir sobre exemplos da ação de antibióticos em colônias de bactérias, continuaram afirmando constituir processo evolutivo, por um motivo substancial: a adaptação, que classificamos como a hipálage adaptação. Para eles 'adaptar-se á' indica processo evolutivo. O exemplo mencionado caracteriza seleção artificial de microorganismos; é comumente citado nos livros didáticos como analogia para explicar a seleção natural, o que pode favorecer interpretações de que a analogia exposta é um caso de seleção natural propriamente dita.

Pode ser! Eu acredito que seja uma evolução! Cada vez existem bactérias mais resistentes, então comparado a outras que não são mais resistentes aqueles antimicrobianos, elas são mais evoluídas (P7). 
Eu acho que sim! Por quê? Exatamente por isso, por que ele se adapta ao meio que está dando para ele, e ele cria algumas formas e alguns mecanismos de se contrapor a esse meio, a essa situação, e ele evolui de alguma forma, não sei, criando alguma enzima, alguma coisa (P2).

Sete sujeitos negaram o processo evolutivo, caracterizando apenas adaptação:

Eu acho que aconteceu adaptação! Por que daí os microorganismos vão se adaptar a esse antibiótico, e com o tempo vão passam a ter maior resistência (P4).

O recurso à genética aparece novamente como um argumento de autoridade nas respostas de três sujeitos.

[...] é difícil falar em adaptação, mas evolução é que não é, por que é muito rápido pra ser evolução [...] A gente sabe a parte física, alteração do DNA, ocorre essas mudanças que passam aos seus descendentes? (P17).

Quanto à sétima questão, no primeiro exemplo obtivemos as categorias: "Características ambientais"; "Características comportamentais"; "Recurso à genética".

Quando foi proposto o exemplo da migração das tartarugas (GOULD, 1989) quatro entrevistados disseram não saber explicar e nem sequer quiseram elaborar um raciocínio. Três professores explicaram esta característica evolutiva das tartarugas pela adaptação ao ambiente, ainda que não soubessem explicar exatamente como essa viagem de volta acontece. Esta atribuição da responsabilidade evolutiva ao ambiente foi, por nós, caracterizada novamente como hipálage adaptação, uma vez que reduz o processo evolutivo à adaptação ao meio.

Não sei! Por causa do ambiente lá na época de se reproduzir [...] Talvez por que elas nasceram lá, elas também vão querer deixar, botar os ovos delas lá (P4).

Outro exemplo de hipálage verificado foi a atribuição de todo processo evolutivo dessa característica nas tartarugas a um "instinto animal", verificado nas respostas de seis professores.

Da tartaruga é instinto eu acho, sei lá [...] Ela vai pela corrente depois volta sem saber como... (P5).

Quatro professores recorreram à explicação genética, utilizando o argumento de autoridade.

Eu acho que os animais na realidade [...] têm assim, como ... um GPS também, antigo [...] Alguma coisa química, que está no DNA dele... (P14). 
Quanto a sétima questão, no segundo exemplo elaboramos as categorias: "Lei do uso e desuso"; "Hipótese dos órgãos vestigiais"; "Recurso à genética".

Quanto a proposta do exemplo dos dentes no feto de baleia (GOULD, 1989), nove professores citaram prontamente a "Lei do uso e desuso" de Lamarck configurando novamente uma repetição do discurso do livro didático, em que este exemplo é muito popular

É interessante se for pensar no uso e desuso... não sei (P1).

[...] assim nós temos o nosso siso, a gente não usa, então ao passar do tempo [...] Mas nós ainda temos o siso... [...] nós tínhamos o alantoide,? [...] aquele anexo embrionário? e sumiu também [...] (P2).

Cinco professores entrevistados citaram os órgãos vestigiais e dois outros (P6 e P17), novamente, fizeram uso do recurso genético para explicar o exemplo.

[...] o filhote, o feto da baleia tem no ventre da mãe, eu acho que são aqueles órgãos vestigiais que evidenciam aí a evolução. Quer dizer, seus ancestrais tiveram mesmo dentes funcionais. (P11).

[...] aconteceu aleatoriamente uma mutação, e isso não foi, desvantajoso pra ele [...] então foi selecionada uma mudança, uma evolução (P6).

\section{Resultados: o que falar quer dizer}

Diante das falas dos professores, criamos sete categorias. A categorização foi elaborada diante da proposição de Mazzotti (2008), identificando as figuras de retórica nas falas dos docentes entrevistados.

Dos discursos dos professores identificamos sete temas centrais que entendemos como a representação do conceito de evolução. Quatro deles são: (evolução é) adaptação, (evolução tem o) ambiente como agente central, (evolução depende da) genética e mudança no organismo. Outros três temas aparecem em segundo plano justificando alguns fatores mais específicos: evolução como processo linear; discurso do livro didático; Darwin opositor de Lamarck.

Para os 17 professores entrevistados, não houve diferenças nos conceitos de evolução e adaptação ao meio. Esses são tratados, muitas vezes, como sinônimos, desconsiderando a dinâmica do processo evolutivo dos seres vivos: a) a necessidade de 
adaptação do ser às condições ambientais (luta pela sobrevivência), b) essa adaptação em parte depende da hereditariedade, em parte é dada pela escolha dos seres vivos ao ambiente; c) condições ambientais e da espécie que favoreça os seres na luta pela sobrevivência; d) as transformações hereditárias e ambientais da população ao longo do tempo de modo a tornar-se uma vantagem para o grupo.

No discurso dos professores a evolução é materializada ora como metáfora da 'seleção natural', ora como metáfora 'adaptação'. Realçamos também, nas falas dos professores, a personificação da noção de adaptação. Em outras palavras, a ideia de adaptação é uma entidade que vem de fora para dentro dos seres vivos e os molda. No processo pelo qual o organismo se adapta em um ambiente, existem duas dimensões importantes para a evolução: espaço e tempo. Na representação dos professores o tempo - de longa duração - e o espaço escolhido pelos seres vivos (ambiente) não são considerados. A adaptação é representada como imposição ambiental que ocorre instantânea e constantemente no espécime.

A mesma representação ocorre no segundo tema; o entendimento dos professores é que o ambiente age ‘forçando' mudanças nos seres vivos, ou seja, o meio é um agente. A evolução é muito citada nas espécies, mas nas argumentações não são fornecidos exemplos pelos professores. Representam apenas os organismos individuais, é o organismo que sofreu a mudança que se adapta, portanto é o indivíduo que evolui. Assim, temos em vista o problema da compreensão de mudança no espécime e não na espécie. O ambiente é representado pela metáfora da sustentação; o ambiente sustenta as relações entre espécies diferentes ou entre os seres vivos e seu ambiente. Não é uma dimensão dessa evolução dos seres vivos.

A ideia de que genes são o agente responsável pela mudança e da adaptação, é o argumento mais utilizado pelos professores. Trata-se de um argumento de autoridade baseado em conceitos da genética; aparece tecido pela figura de retórica hipálage genética, figura que reduz a evolução pelos conhecimentos da genética.

Essa representação é interessante do ponto de vista teórico e epistemológico porque denota um criacionismo molecular dirigindo o velho criacionismo religioso. A genética é representada como uma entidade criativa, responsável por formar novas espécies e solucionar eventuais problemas de características incompatíveis na luta pela sobrevivência (melhorar o espécime). Essa representação está clara nas respostas das questões 6 e 7 em que os professores afirmam que a sobrevivência de alguns microorganismos, pelo fenômeno peculiar de migração, ou ainda a ocorrência de órgãos 
vestigiais é o DNA, como se esta sigla resumisse que é algo além da explicação, sobrenatural ou autojustificável.

A genética, ou a sua personificação, o DNA, é um recurso intelectual utilizado quando não se tem outra explicação ou um termo inquestionável.

Charles Darwin é representado como um naturalista que melhorou os trabalhos de Lamarck; estes são vistos como rivais em termos teóricos. No discurso dos professores a repercussão da teoria de Darwin se deve ao rompimento com o modelo religioso de origem da vida. Assim é representado para a maioria dos professores que não exercem o magistério, enquanto a importância científica filosófica da teoria é mencionada pelos professores em exercício, denotando conhecimento dos documentos curriculares oficiais.

Para a maioria dos professores que não estava em exercício a importância do estudo de evolução está em solucionar a incógnita da origem dos seres vivos e do homem e prever o futuro da vida humana. Para os professores em exercício, o discurso evidencia a relevância da evolução na biologia, conforme explicitação dos documentos oficiais para os currículos escolares. Não podemos afirmar no contexto de nossa pesquisa que há, pelos professores em exercício, reconhecimento da importância da teoria darwiniana, ao avaliarmos todas as outras respostas equivocadas que estes nos forneceram.

A representação social da evolução dos seres vivos em relação ao tempo é dada por uma visão de processo linear, pelo uso da figura de retórica metáfora da escada. $\mathrm{O}$ tempo evolutivo não é considerado nos processos evolutivos; não emerge a noção de escala de tempo biológico, a noção de bilhões e/ou milhões de anos.

Os livros didáticos aparecem como os recursos pedagógicos hegemônicos. Os entrevistados utilizam o discurso do livro didático citando os mesmos exemplos nele contidos; desconhecem outros exemplos de evolução animal ou vegetal. Não entendem a seleção artificial e utilizam principalmente exemplos animais, os demais reinos são ignorados; o papel da paleontologia e da ecologia é pouco lembrado nos estudos evolutivos.

Por fim, consideramos que a teoria de evolução de Darwin se constitui como RS entre os professores que participaram de nossa pesquisa. Afirmamos que as RS de evolução se vinculam à metáfora de progresso.

As referências à evolução são feitas, sobretudo como seleção natural. Isso significa que a teoria é compreendida apenas por um dos postulados de Darwin, 
indicando que a teoria de Darwin, quando tratada no meio escolar, meio social em que circulam crenças e valores diferentes das comunidades científicas, sofre a intervenção de outros operadores, ou de outras representações.

A representação de uma evolução intencional, com determinações dos genes ou de determinação de um agente externo retira do conceito de evolução postulado por Darwin a dinâmica, o papel do acaso e a noção de que não há evolução para o melhoramento da espécie ou seu progresso, não há o melhor ou pior organismo.

\section{Conclusão}

A Representação Social do conceito de evolução dos professores está ancorada na metáfora de progresso. Para tal sustentação os professores recorreram à genética, deixando de pensar a dinâmica entre ambiente e seres. Embora não tenhamos nenhuma afirmação criacionista, a crença de que os genes direcionam a evolução dos seres levanos pensá-los como agentes que têm intenção, vontade própria.

Os conceitos influenciados por representações operadas no reino de crenças, como a de progresso e de intenção da natureza negligenciam a educação em Ciências, sobretudo em um campo em que a necessidade de modelos abstratos é muito importante como no ensino da evolução. Essa lacuna e a incompreensão da evolução biológica postulada por Darwin implicam em lacunas na aprendizagem dos processos biológicos inclusive na genética.

\section{Referências}

ALVES-MAZZOTTI, A. J. Fracasso escolar e suas relações com o trabalho infantil: representações de alunos repetentes, trabalhadores e não-trabalhadores e de seus professores. In: MENIN, M. S. S.; SHIMIZU, A. M. (org). Experiência e representação social: questões teóricas e metodológicas. São Paulo: Casa do Psicólogo, 2005.

ALVES-MAZZOTTI, A. J.; GEWANDSZNAJDER, F. O Método nas Ciências Naturais e Sociais. Pesquisa Quantitativa e Qualitativa. São Paulo: Tomson, 1998.

BRASIL. Brasília; Ministério da Educação, Secretaria de Educação Básica. Orientações curriculares para o ensino médio, Ciências da natureza, matemática e suas tecnologias. Volume 2. 2006.

CAPONI, G. O darwinismo e seu outro, a teoria transformacional da evolução. Scientia e Studia, SãoPaulo, v. 3, n. 2, p. 233- 242. 2005. 
CAPONI, G. El viviente y su médio: Antes y después de Darwin. Scientia e Studia, SãoPaulo, v. 4, n. 1, p. 154. jan- mar. 2006.

DARWIN, C. A origem do homem e a Seleção Sexual. Tradução: Attílio Cancian e Eduardo Nunes Fonseca. São Paulo: Hemus, 1974.

DARWIN, C. A origem das Espécies. Tradução: John Green. 2. ed. São Paulo: Martin Claret, 2009.

DEWEY, J. The influence of Darwin on philosophy and other essays. New York: Prometheus books, 1997.

DOBZHANSKY, T. H. Nothing in Biology makes sense except in the light of evolution. American Biology Teacher, 35, p.125-129. 1973.

FUTUYMA, D. J. Evolução, Ciência e Sociedade. São Paulo: Sociedade Brasileira de Genética, 2002.

GOEDERT, L. A formação do professor de biologia na UFSC e o ensino da evolução biológica. Dissertação (Mestrado em Educação Científica e Tecnológica). Florianópolis: Universidade Federal de Santa Catarina - UFSC, 2004.

GOULD, S. J. O Polegar do Panda. Reflexões sobre história natural. Tradução: Carlos Brito; Jorge Branco. São Paulo: Martin Fontes, 1989.

GOULD, S. J Escadas e cones: coagindo a evolução por meio de ícones canônicos. In: SILVERS, R. B. (org). Histórias esquecidas da ciência. Tradução: Gilson César Cardoso de Sousa. Rio de Janeiro: Paz e Terra, 1997.

JODELET, D. (org). As Representações Sociais. Tradução: Lilian Ulup. Rio de Janeiro: EdUERJ, 2001.

LAKOFF, G.; JOHNSON, M. Metáforas da vida cotidiana. Tradução: Mara Sophia Zanotto. Campinas, SP: Mercado das letras; São Paulo: Educ, 2002.

MADEIRA, M. C. Os processos de objetivação e de ancoragem no estudo das representações sociais de escola. In: MENIN, M. S. S.; SHIMIZU, A. M. (org). Experiência e representação social: questões teóricas e metodológicas. São Paulo: Casa do Psicólogo, 2005.

MAZZOTTI, T. B. Para uma "pedagogia das representações sociais". Educação e Cultura Contemporânea, Rio de Janeiro, v. 6, n. 11, p. 121-142, jul/dez. 2008.

MEYER, D.; EL-HANI, C. N. Evolução: O sentido da biologia. São Paulo: UNESP, 2005.

MOSCOVICI, S. Representações Sociais. Investigação em Psicologia Social. Tradução: Pedrinho A. Guarieschi. 6. ed. Petrópolis, RJ: Vozes, 2009. 
PARANÁ. Curitiba; Secretaria de Estado da Educação do Paraná, Departamento de Educação Básica. Diretrizes Curriculares da Educação Básica. Biologia. 2008.

PERELMAN, C.; TYTECA, L. O. Tratado da Argumentação. A nova retórica. Tradução: Maria Ermantina Galvão. São Paulo: Martins Fontes, 2000.

REBOUL, O. Introdução à retórica. Tradução: Ivone Castilho Benedetti. 2. ed. São Paulo: Martins Fontes, 2004.

ROJAS SORIANO, R. Manual de pesquisa social. Tradução: Ricardo Rosenbusch. Petrópolis, RJ: Vozes, 2004.

ROQUE, I. I. Girafas, mariposas e anacronismos didáticos. Ciência Hoje, São Paulo, v. 34, n. 200, p. 64-67. 2003.

SACARRÃO, G. F. Biologia e Sociedade. Crítica da Razão Dogmática. Portugal: Publicações Europa-América, 1989. 